\title{
Keserasian Dua Dunia yang Berbeda: Relasi ASEAN-EU dalam Kerja sama Multilateral
}

\author{
Rr. Nurul Rahmah C.P., Ridwan Stanley Sinaga, Adi Fadhilah Nurul Rahman, Enno Nuri Al \\ Sarah, Hari Agung Satya Wicaksana, Mutiara Megantari Putri, Khansa Hanun Augie \\ Universitas Diponegoro
}

\begin{abstract}
Cooperation could be done by integrated cooperation between states member and inter regional organization equally, like ASEAN and EU (Eropean Union) cooperation. Popular speculations between this two organizations are mostly partial, biased in gap between EU contribution to ASEAN rather than vice versa. In this paper, we challenge capability of ASEAN as a regional organization with most of the member states are developing and third world country comparing to EU which 26 of members states has highest GDP all around the world. This paper also discuss about ASEAN as an organization that have eperiences in several humanitarian violation cases, comparing with EU as a 'safe heaven' in human rights. Through ecleckticism theory, we would see how liberalism and realism played a role in seeing such phenomenon, and how to see between those two theories. This paper argEUs that there are mutuliasm cooperations between EU and ASEAN, start with EU contribution on ASEAN structures, the critics about ASEAN as 'imitation community', and also being partner with ASEAN in investments. ASEAN is also seen as a 'teacher' for EU in pragmatism and normative power to improve EU capability as inclusive community.
\end{abstract}

Keywords: trade, hegemony, multilateral, EU, ASEAN

\begin{abstract}
Abstrak
Kerja sama dapat dilakukan dalam bentuk kerja sama terintegrasi antara negara satu dengan negara lainnya, serta dapat pula dilakukan dalam bentuk kerja sama antara suatu organisasi regional dengan organisasi regional lainnya, seperti ASEAN dengan EU (EU). Spekulasi yang paling terkenal dari hubungan kedua organisasi ini yaitu ketimpangan diantara keduanya, yang lebih condong ke ketimpangan antara kontribusi EU ke ASEAN dibanding sebaliknya. Dalam tulisan ini, kami membahas tantangan dari kemampuan yang dimiliki oleh ASEAN sebagai organisasi regional yang kebanyakan dari negara anggotanya adalah negara berkembang dan negara dunia ketiga dibandingkan dengan EU yang dimana 26 negara anggotanya merupakan negara berpenghasilan tertinggi di dunia. Selain itu, dibahas juga kemampuan ASEAN dalam menangani berbagai kasus pelanggaran terhadap kemanusiaan dibandingkan dengan EU yang dikenal sebagai tempat yang aman untuk hak asasi manusia. Melalui teori eklektisisme, kita dapat melihat bagaimana liberalisme dan realisme berperan dalam melihat fenomena kerja sama ini, dan bagaimana melihat diantara keduanya. Tulisan ini berargumen bahwa ada kerja sama yang saling menguntungkan antara EU dan ASEAN, mulai dari kontribusi EU dalam stuktur ASEAN yang kemudian ASEAN di kritik sebagai 'immitation community' dan sebagai partner investasi ASEAN. Selain itu ASEAN juga berperan sebagai guru bagi EU dalam hal pragmatism dan kekuatan normatif untuk memngembangkan kemampuan EU sebagai komunitas inklusif.
\end{abstract}

Kata-kata kunci: perdagangan, hegemoni, multilateral, EU, ASEAN 


\section{Pendahuluan}

EU (EU) dan Association of Southeast Asian Nations (ASEAN) merupakan dua kawasan dengan proses integrasi paling maju di dunia. Kedua organisasi berkomitmen menyelesaikan masalah melalui pendekatan multilateral dan memandang integrasi kawasan sebagai cara paling efektif untuk membangun stabilitas, kemakmuran, serta menghadapi tantangan global (European External Action Service, 2018). Hubungan kerja sama antara ASEAN-EU diinisiasi oleh ASEAN sekitar tahun 1970an. Hal ini dilakukan sebagai respon terhadap perubahan ekonomi di Eropa dan pergeseran dalam persamaan kekuatan di Asia. Hingga saat ini, kerja sama di antara keduanya telah mengalami peningkatan yang signifikan dalam bidang ekonomi dan pembangunan, secara khusus pada pembangunan negara-negara anggota ASEAN.

Pada dasarnya, terdapat perbedaan yang mencolok di antara ASEAN-EU. Dalam struktur dan kelembagaannya, EU telah memiliki berbagai bidang yang memiliki fungsi masing-masing, sementara ASEAN tidak. ASEAN merupakan organisasi yang berintegrasi terbuka, yang memberikan keleluasaan bagi para anggotanya untuk mengadakan perjanjian perdagangan di luar kerangka ASEAN tanpa intervensi. Hal ini berbanding terbalik dengan EU yang berintegrasi tertutup. Dilihat dari sudut pandang ekonomi, ASEAN dan EU juga memiliki perbedaan yang cukup signifikan. Pada tahun 2016, total GDP ASEAN mencapai jumlah US\$ 2.55 triliun (ASEAN, 2017), sedangkan GDP EU mencapai angka US\$17,4 Triliun pada tahun yang sama (European Union, 2018).

Melihat kenyataan tersebut, maka muncul dua pertanyaan yang akan di jawab dalam paper ini. Pertama, apakah kerja sama antara ASEAN dan EU bersifat saling menguntungkan atau timpang? Kedua, dalam hal apakah ASEAN belajar dari EU dan dalam hal apa EU dapat belajar dari ASEAN?

Perbedaan yang sangat signifikan diantara kedua organisasi tersebut membuat kerja sama yang terjalin di antara ASEAN dan EU terlihat hanya menguntungkan satu pihak saja, yaitu ASEAN. Sementara di sisi lain, EU dianggap tidak mendapat keuntungan signifikan. Tercatat, perekonomian negara-negara ASEAN telah meningkat lebih dari tiga kali lipat dalam sepuluh tahun terakhir, serta telah menjadi salah satu negara dengan perkembangan ekonomi yang pesat di Asia. Bahkan, total perdagangan barang bilateral antara EU dan ASEAN ada yang menembus US $\$ 28,8$ miliar pada tahun 2015, dengan total ekspor barang dari EU sejumlah US\$11 miliar. Sementara itu, ekspor dari beberapa negara ASEAN ke EU mencapai US\$16,4 miliar, yang berarti ASEAN menerima surplus dari kegiatan ekspor ini senilai US\$5,4 miliar. Indonesia sebagai salah satu negara ASEAN menargetkan EU sebagai tujuan ekspor terbesar ke-2 pada tahun 2015, yang 
mencapai angka 11,2\% dari keseluruhan total ekspor Indonesia ke seluruh dunia. Pada tahun 2015, Indonesia menempati peringkat ke-30 partner dagang EU di seluruh dunia (European External Action Service, 2018). Selain itu, EU juga memberikan dukungan terhadap pendidikan tinggi Indonesia. Melalui program Erasmus+, EU menganugerahi lebih dari 100 sarjana Indonesia untuk belajar di Eropa pada tahun 2015. Saat ini, sekitar 9.000 mahasiswa Indonesia belajar di Eropa, dan 1.600 diantaranya telah menerima gelar sarjana dari negara anggota EU (European External Action Service, 2018). Oleh karena itu, kerja sama yang ASEAN-EU tampaknya hanya menguntungkan ASEAN. ASEAN dirasa tidak memberikan sumbangsih apapun kepada EU dalam kerjsasama dibidang ekonomi, politik, maupun pendidikan.

Paper ini berpendapat bahwa relasi ASEAN-EU pada faktanya menghasilkan hubungan simbiosis mutualisme, dan kedua pihak mendapatkan keuntungan dari kerja sama yang ada. Berbagai wujud kerja sama ASEAN-EU menempatkan EU sebagai investor yang memberikan modal kepada negara ASEAN untuk mengembangkan usaha dalam negeri serta menyediakan lapangan pekerjaan baru, sehingga dapat membantu mengurangi angka pengangguran di negara-negara tersebut. Selain itu, EU juga merupakan tujuan utama ekspor bagi ASEAN. Di sisi lain, EU juga memperoleh keuntungan dari kerja sama ini. Selain menjadi tujuan utama ekspor, ASEAN juga menjadi pintu gerbang bagi EU untuk masuk ke dalam kawasan Asia-Pasifik. Hal ini membuktikan bahwa ASEAN membantu EU untuk memperluas pasarnya, yang secara eksplisit akan memberikan tambahan keuntungan bagi EU. Keuntungan lainya yang di dapat oleh EU adalah kesempatan untuk menonjolkan identitas serta peran EU dalam dunia internasional, secara khusus di wilayah Asia Tenggara. Sejak kedua organisasi ini menjalin hubungan kerja sama, baik ASEAN maupun EU dapat saling mempelajari berbagai hal satu sama lain. Terdapat banyak program ASEAN yang terinspirasi dari EU, dan sebaliknya, EU juga dapat belajar mengenai penanganan persoalan masyarakat yang heterogen.

Paper ini diawali dengan penjelasan tentang eklektisisme, dimana penulis menggunakan kolaborasi antara liberalisme dan konstruktivisme dalam menjelaskan hubungan kerja sama yang terjalin antara ASEAN dan EU. Selanjutnya, paper ini akan memberi pemaparan terkait hubungan kerja sama ASEA-EU, apakah hubungan yang terjalin di antara keduanya saling menguntungkan atau timpang. Selanjutnya, paper ini akan menjelaskan mengenai pelajaran yang dapat diperoleh oleh masing-masing ASEAN dan EU dari kerja sama yang telah dijalin. 


\section{Pendekatan Elektisisme}

Sejak awal berdirinya di awal abad ke-20, ilmu hubungan internasional telah dibagi menjadi beberapa kubu, yaitu realisme dan idealisme, behaviorisme dan tradisionalisme, neoliberalisme dan neorealisme, dan rasionalisme dan konstruktivisme. Saat ini, persaingan paling dominan terjadi antara realisme, liberalisme, dan konstruktivisme. Ketiga teori ini memiliki perbedaan yang sangat signifikan memandang dan menganalisa sebuah fenomena. Dengan demikian, dalam konteks perdebatan antara realis, liberal, dan konstruktivis mengenai studi politik dunia, elektisisme politik menjadi salah satu konsep alternatif yang paling tepat digunakan.

\section{Gambar. 1. Diagram Eklektisisme}

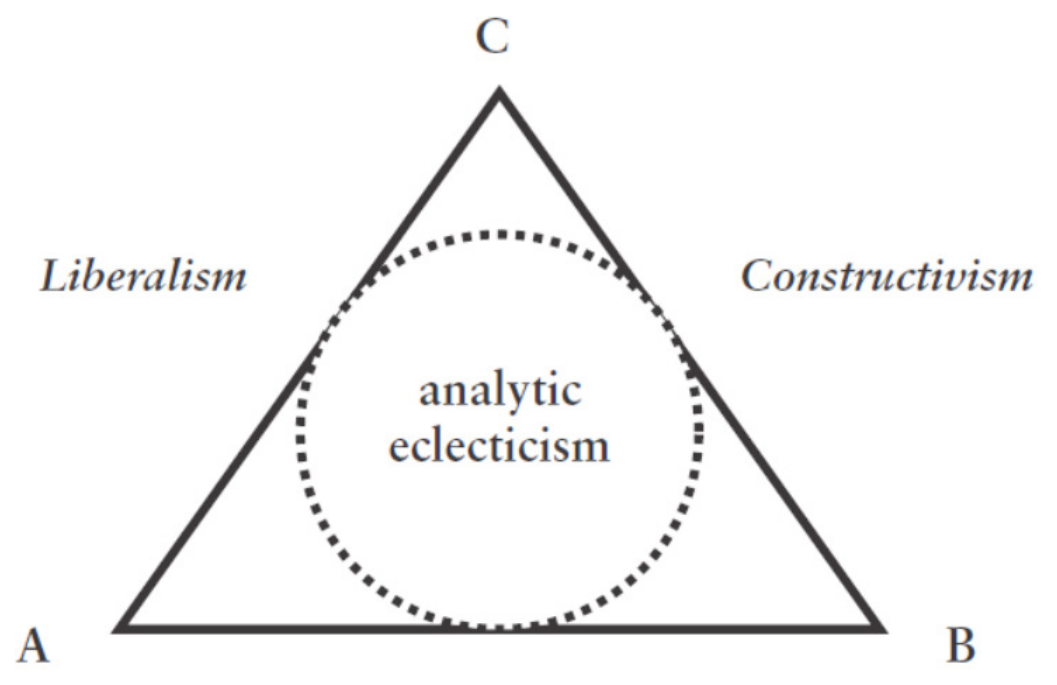

\section{Realism}

Sumber : (Sil \& Katzenstein, 2010)

Gambar diatas menggambarkan konstruktivisme, liberalisme, dan realisme sebagai tiga sisi segitiga. Penelitian eklektik ini mengeksplorasi titik-titik hubungan antara setidaknya dua, atau ketiga dari sisi tersebut. Ketiga paradigma biasanya dibedakan berdasarkan asumsi inti tertentu tentang sifat kehidupan internasional, misalnya dalam prioritas terkait identitas dan norma, kepentingan dan keuntungan yang efisien, atau kemampuan untuk distribusi material. Masing-masing paradigma utama mencakup pemahaman yang dapat dibedakan dalam hal prioritas yang ditetapkan untuk asumsi ontologis, epistemologis, dan substantif yang berbeda, yang biasanya terkait dengan paradigma tersebut. Heterogenitas pendekatan yang dihasilkan dalam paradigma tersebut menunjukkan ketiga teori tersebut mungkin tidak koheren, seragam, dan kaku seperti yang sering diasumsikan. Kedua, karena heterogenitas internal mereka, masing-masing paradig- 
ma telah menghasilkan argumen substantif yang cukup luas, beberapa di antaranya bersatu dengan argumen yang dikembangkan dalam paradigma lain tentang isu dan kebijakan tertentu. Ini mungkin tidak menandai akhir perdebatan antar paradigma, seperti yang diharapkan beberapa orang.

Sudut C pada gambar diatas menjelaskan saat di mana konstruktivisme dan liberalisme bertemu. Liberalisme klasik dan konstruktivisme sama-sama memberi penekanan pada bagaimana interaksi ide, berbagi ilmu pengetahuan, prinsip-prinsip hukum yang muncul dan lembaga multilateral dapat membentuk kembali identitas dan preferensi aktor, dan melahirkan pemahaman timbal balik dan tingkat kerja sama yang tidak dapat direduksi menjadi negara yang tetap (Haas 2001; Reus-Smit 2001). Bagi beberapa kaum liberal dan konstruktivis, kesamaan ini begitu signifikan sehingga mereka memilih untuk mengatasi perbedaan mendasar dalam ontologi dan condong ke arah orientasi liberal konstruktivis (Jackson \& Nexon, 2009). Beberapa pendukung konstruktivisme realis mengkarakterisasi konstruktivisme konvensional sebagai rekonstruksi alternatif idealisme liberal (Barkin, 2003). Pada sudut A, fitur rasionalis yang memungkinkan konvergensi antara pendekatan neoliberal dan neorealis, digambarkan dalam pandangan yang lebih luas tentang teori liberal. Kurangnya fokus pada preferensi aktor dan rasionalitas strategis, dan lebih banyak pada proses kompleks yang mengarah pada munculnya kerja sama dalam konteks tertentu. Sehubungan dengan proses-proses ini, konstruktivisme konvensional dan liberalisme klasik dapat dijadikan sebagai pelengkap (SterlingFolker, 2000). Beberapa pakar konstruktivis (Steele, 2007) melihat langkah ini sebagai langkah yang meruntuhkan fondasi konstruktivisme yang berbeda dan melemahkan kemampuannya untuk menantang teori realis dan liberal mainstream. Namun, untuk melonggarkan komitmen paradigmatik yang mendukung asumsi praktis yang dapat memandu penelitian substantif yang berfokus pada masalah, maka ada alasan untuk mempertimbangkan beberapa kesamaan antara untaian spesifik liberalisme dan konstruktivisme.

Dalam pembahasan kasus eklektisisme yang lebih besar dalam hubungan internasional, perlu digarisbawahi bahwa terdapat komitmen epistemik yang berbeda. Paradigma dan tradisi penelitian biasanya tidak begitu kaku sehingga menghasilkan produk penelitian yang seragam dan yang secara prediktif menyatu pada interpretasi, penjelasan, atau resep yang substantif. Dalam melibatkan masalah-masalah tertentu, sangat mungkin bagi para konstruktivis, liberal, maupun realis untuk tidak sepakat terkait pandangan maupun konsep dari satu sama lain, sementara beberapa jenis realis, liberal, dan konstruktivis mungkin dapat menyatu pada karakterisasi substantif dari, dan formula untuk masalah tertentu di dunia internasional. Konvergensi semacam itu merunjuk pada kemungkinan dan kegunaan eklektisisme dalam studi politik dunia 
Paper ini menggunakan kolaborasi antara liberalisme dan konstruktivisme dalam memandang hubungan yang terjalin antara ASEAN dan EU (di sudut C pada Gambar 2.1). Liberalisme klasik, khususnya, berbagi dengan konstruktivisme penekanan pada bagaimana interaksi ide, berbagi pengetahuan, prinsip-prinsip hukum yang muncul dan lembaga multilateral dapat membentuk kembali identitas dan preferensi aktor, dan melahirkan pemahaman timbal balik dan tingkat kerja sama yang tidak dapat direduksi menjadi minat negara (Haas 2001; Reus-Smit 2001). Untuk beberapa kaum liberal dan konstruktivis, kesamaan ini begitu signifikan sehingga perlu dilakukan pembatasan mengenai perbedaan mendasar dalam ontologi dan condong ke arah orientasi liberal konstruktivis (Jakscon \& Nexon, 2009). Beberapa pendukung konstruktivisme realis mengkarakterisasi konstruktivisme konvensional sebagai rekonstruksi alternatif idealisme liberal (Barkin, 2003). Fitur rasionalis yang memungkinkan konvergensi antara pendekatan neoliberal dan neorealis (di sudut A) didiskontokan dalam pandangan yang lebih luas tentang teori liberal; sehingga mengurangi fokus pada preferensi aktor dan rasionalitas strategis, dan lebih banyak pada proses kompleks yang mengarah pada munculnya kerja sama dalam konteks tertentu. Sehubungan dengan proses-proses ini, konstruktivisme konvensional dan liberalisme klasik dapat diperlakukan sebagai pelengkap daripada bersaing (SterlingFolker, 2000). Beberapa konstruktivis (Steele, 2007) melihat langkah ini sebagai meruntuhkan fondasi konstruktivisme yang berbeda dan melemahkan kemampuannya untuk menantang teori realis dan liberal mainstream. Namun, untuk melonggarkan komitmen paradigmatik yang mendukung asumsi praktis yang dapat memandu penelitian substantif yang berfokus pada masalah, maka ada alasan untuk secara serius mempertimbangkan beberapa kesamaan antara untaian spesifik liberalisme dan konstruktivisme, setidaknya untuk pertanyaan-pertanyaan tertentu.

\section{Hubungan Saling Menguntungkan ASEAN-EU}

Berakhirnya Perang Dunia Kedua memicu munculnya fenomena-fenomena politik baru dalam politik global, yaitu munculnya kerja sama dan integrasi negara dalam suatu kawasan dalam skala kontinental (Christainsen, 2001). EU dapat dijadikan sebagai salah satu contoh dalam mendefinisikan dan menjelaskan mengenai kerja sama kawasan. Hal tersebut dikarenakan kerja sama EU telah menjadi salah satu kekuatan ekonomi dunia yang belum bisa ditemukan di tempat lain, ketika kawasan lain masih sedang berusaha menuju ke arah kerja sama yang lebih terintegrasi. EU telah terintegrasi dan menciptakan entitas ekonomi Eropa dengan mata uang tunggal, yakni euro (Winarno, 2014). Selain itu, EU juga mempunyai perangkat kerja sama yang cukup lengkap bahkan mereka pun juga mampu untuk menciptakan suatu bentuk polity baru (Christainsen, 2001). 
Ketika EU sudah memiliki sistem yang lengkap dan sudah terintegritas dengan baik, masih ada beberapa kawasan lain yang masih dalam keadaan kurang baik sebagai akibat disparitas yang sangat tinggi di antara negara negara anggotanya. Misalkan saja ASEAN, sebagai salah satu organisasi kerja sama kawasan yang mencakup bidang sosial, budaya, dan juga ekonomi yang sejak akhir 1960an. Pada awal terbentuknya, struktur ASEAN tidak berjalan baik karena konflik ideologis. Di sisi lain, negara-negara anggota ASEAN kecuali Singapura, merupakan negara agraris sehingga tidak ada kesempatan kerja sama saling mengisi (Rangganawati, 2005).

Meski demikian, kerja sama antara EU-ASEAN tetap bisa terlaksana. Salah satunya yaitu kerja sama dengan Indonesia, sebagai bagian dari ASEAN, sejak tahun 1967. EU yang pada saat itu masih berwujud EEC atau European Economic Community, untuk pertama kalinya menjalin hubungan kerja sama dengan ASEAN (Kementerian Luar negeri Indonesia, 2008). EU yang secara kelembagaan merupakan sebuah integrasi kawasan regional negara Eropa telah mengalami fase-fase perkembangan yang kompleks dan mengakar. Terdiri dari 27 negara anggota yang memiliki Pendapatan Domestik Bruto (PDB) terbesar di dunia, EU tentunya memiliki standar yang tinggi baik pada aspek birokrasi tetapi juga khususnya pada aspek regulasi. Mulai dari standar operasional, prosedur, hingga syarat-syarat yang tinggi harus dipenuhi oleh Indonesia sebelum mendapatkan persetujuan untuk masuk dan bersaing secara mandiri di pasar EU.

Sekilas hubungan antara ASEAN dan EU terlihat timpang dan hanya menguntungkan satu pihak saja yakni ASEAN. Sedangkan disini EU terlihat sama sekali tidak mendapatkan keuntungan dari kerja sama regional tersebut bahkan dirasa merugikan EU. Namun, relasi antara kedua regional tersebut justru saling menguntungkan. Jika dianalisis, hubungan antara EU dan ASEAN bisa dikatakan positive sum game dimana kondisi dimana jumlah keuntungan dan kerugian dari seluruh peserta yang terlibat adalah positif (Jackson, 2009).

Dalam hal ini, keuntungan yang bisa didapat ASEAN adalah dengan menjadikan EU sebagai investor yang bisa menunjang pembangunan ataupun mengembangkan potensi ekonomi negara anggota ASEAN. Dari kerja sama ini ASEAN dapat menjadikan EU sebagai investor yang memberikan modal kepada para negara anggota untuk mengembangkan usaha dalam negerinya dan untuk menyediakan lapangan pekerjaan baru, yang tentunya dapat membantu para negara anggota. Salah satu contohnya adalah mengenai Program Enhanced Regional EU-ASEAN DialogEU Instrument (E-READI) dan Enhanced ASEAN Regional Integration Support from the EU (ARISE Plus) . Kedua program ini menjadi program unggulan dari kerja sama pembangunan EU di ASEAN dengan keseluruhan dana senilai US\$61 juta European (External Action Service, 2018). 
E-READI merupakan program kerja sama yang memfasilitasi forum dialog antara EU dan ASEAN dalam area kebijakan di seluruh pilar Komunitas ASEAN (politik dan keamanan, ekonomi dan sosial-budaya). Dengan dana senilai US $\$ 21$ juta dan implementasi selama enam tahun, E-READI melanjutkan pencapaian program sebelumnya, yaitu READI, serta membantu ASEAN lebih lanjut dalam pengembangan dan implementasi strategi integrasi regional dan pembangunan komunitas, didukung oleh pengalaman EU yang relevan (External Action Service, 2018).

Selain itu, ASEAN juga mengalami surplus dalam perdagangan dengan EU, terutama untuk produk peralatan kantor dan telekomunikasi, produk pertanian, dan pakaian. Dari segi investasi, EU adalah sumber investasi langsung terbesar bagi ASEAN. Investasi EU di ASEAN ditujukan untuk sektor industri, pertambangan, dan keuangan. Sebaliknya, keuntungan yang juga diperoleh oleh EU adalah kesempatan untuk menjadikan ASEAN sebagai pintu gerbang bagi EU untuk masuk ke dalam kawasan Asia Pasifik. Hal ini membuktikan bahwa ASEAN membantu EU untuk memperluas pasarnya serta pengaruhnya di dunia internasional.

Terciptanya free flow of investment merupakan salah satu tujuan dari ASEAN Investment Forum. Untuk itu, perlu dipetakan terlebih dahulu besarnya arus Foreign Direct Investment (FDI) ke negara-negara ASEAN yang menjadi proksi dalam menghitung investasi yang masuk ke negara-negara ASEAN. Jika angka FDI cukup baik, maka dapat dipastikan bahwa potensi investasi ke ASEAN juga cukup baik. Secara keseluruhan, FDI Inflow ke ASEAN dari secara total berdasarkan asal negara tergambar sebagai berikut:

Tabel. 1. Daftar Investor ASEAN

\begin{tabular}{|l|r|r|r|r|r|r|}
\hline Source Country & \multicolumn{1}{|r|}{2003} & \multicolumn{1}{|c|}{2006} & \multicolumn{1}{|c|}{2007} & \multicolumn{2}{|c|}{2008} & \multicolumn{2}{|c|}{2009} & Share in 2009 \\
\hline ASEAN & 2,702 & 7,756 & 9,682 & 9,568 & 5,172 & 13,1 \\
\hline Australia & 157 & 317 & 1,491 & 880 & 671 & 1,7 \\
\hline Canada & 101 & 255 & 394 & 792 & 488 & 1,2 \\
\hline China & 187 & 1,046 & 1,684 & 2,100 & 1,606 & 3,8 \\
\hline EU27 & 6,679 & 13,159 & 17,766 & 9,249 & 7,523 & 19,1 \\
\hline India & 102 & -282 & 1,466 & 691 & 970 & 2,5 \\
\hline Japan & 3,908 & 110,440 & 8,829 & 4,582 & 5,961 & 15,1 \\
\hline New Zealand & 88 & -209 & 101 & -177 & 231 & 0,6 \\
\hline Pakistan & 2 & 10 & 21 & 6 & 8 & 0,0 \\
\hline Republic of Korea & 550 & 1,246 & 2,716 & 1,663 & 1,500 & 3,8 \\
\hline Russia & & & & & & \\
\hline USA & 1,496 & 3,018 & 8,068 & 4,812 & 3,006 & 0,4 \\
\hline Rest of the World & 8,096 & 18,001 & 21,180 & 15,122 & 11,499 & 29,6 \\
\hline Unspecified & 168 & 1,597 & 967 & 309 & 695 & 1,8 \\
\hline Total & 24.235 & 56.355 & 74.395 & 49,469 & 39,387 & 100,0 \\
\hline
\end{tabular}

Sumber: ASEAN Community in Figure, 2010 
Berdasarkan tabel, terlihat bahwa Porsi FDI antar sesama negara ASEAN mencakup persentase yang cukup tinggi setelah EU $(19,1 \%)$ dan Jepang (15,1\%). Negara sumber FDI lainnya di ASEAN adalah AS mencapai 7,6\%.

ASEAN memiliki potensi yang besar dalam menarik FDI. Berdasarkan laporan WIPS, disamping unsur pertumbuhan dan ukuran pasar, responden WIPS mengindikasikan bahwa terdapat beberapa negara memiliki lokasi yang mendukung misalnya untuk pertumbuhan pasar maka Indonesia, Thailand, dan Vietnam merupakan negara berkembang yang diminati. Tabel berikutnya menunjukkan bahwa untuk kawasan ASEAN, investor lebih tertarik dengan pertumbuhan pasar dan tenaga kerja yang murah daripada ukuran pasar, kepastian supplier, lingkungan bisnis, keahlian, dan akses ke pasar modal

\begin{tabular}{|l|l|l|}
\hline Description & Others & ASEAN \\
\hline Market Growth & $\begin{array}{l}\text { China, India, Brazil, The } \\
\text { Russian Federation, and Poland }\end{array}$ & $\begin{array}{l}\text { Indonesia, Vietnam, and } \\
\text { Thailand }\end{array}$ \\
\hline Market Size & $\begin{array}{l}\text { USA, Germany, Canada, China, } \\
\text { The Russian Fed, and Brazil }\end{array}$ & \\
\hline Access to Regional Market & Mexico, Germany, and Poland & Vietnam \\
\hline Presnce of Supplier & $\begin{array}{l}\text { UK, Germany, France, and } \\
\text { India }\end{array}$ & \\
\hline Bussiness Environment & $\begin{array}{l}\text { USA, Germany, France, and } \\
\text { Australia }\end{array}$ & \\
\hline Skill and talent & $\begin{array}{l}\text { USA, Germany, UK, France, } \\
\text { and India }\end{array}$ & Thailand \\
\hline Cheap Labour & China and India & $\begin{array}{l}\text { Indonesia, Vietnam, } \\
\text { Thailand }\end{array}$ \\
\hline Access to Natural Resource & Canada and Australia & Indonesia \\
\hline Access to Capital Market & UK, USA, and Canada & Vietnam \\
\hline Incentives & Australia an Brazil & \\
\hline
\end{tabular}

Sumber: WIPS (World Investment Prospects Survey, 2009-2011)

Potensi yang dimiliki ASEAN menjadi salah satu alasan bagi EUA melakukan kerja sama investasi. Hal tersebut dikarenakan terdapat beberapa negara di ASEAN yang memang pertumbuhan pasarnya cukup tinggi seperti Indonesia, Vietnam, dan Thailand. Selain itu, akses terhadap ketersediaan sumber daya alam yang ada di ASEAN pun juga menjadi daya tarik yang lebih di banding negara negara lain.

\section{EU Sebagai Guru Integrasi Regional}

Konstruktivis memiliki perspektif sendiri mengenai kerja sama. Kaum konstruktivis berpendapat bahwa organisasi internasional dapat dianalogikan sebagai seorang guru yang dapat memiliki fungsi untuk mengajarkan nilai-nilai atau norma-norma dan ilmu pengetahuan kepada 
muridnya. Dalam tulisan Martha Finnemore yang berjudul International Organization As a Teacher; United Nations Educational, Scientific, and Cultural Organization and Science Policy, Finnemore menganalogikan organisasi internasional sebagai guru yang dapat mengajarkan nilai-nilai kepada muridnya yakni negara-negara (Finnemore, 1993) . Organisasi internasional yang terdiri dari banyak negara dipercaya memiliki kesempatan untuk dapat mengumpulkan informasi dari berbagai negara, serta mampu menyebarkan informasi tersebut kedalam bentuk norma ataupun ilmu pengetahuan yang menjadi acuan untuk digunakan negara dalam bertindak atau bersikap. Norma yang diajarkan organisasi internasional dapat menjadi anutan oleh negara-negara di dunia. Dalam perpektif konstruktivisme, norma dianggap sebagai bagian dari struktur internasional yang terkonstruksi secara sosial, dan sesuatu yang dianggap pantas (baik) oleh komunitas internasional akan kemudian dapat mendorong negara-negara di dunia untuk turut menerapkannya dalam bertindak atau bersikap.

EU sebagai salah satu contoh organisasi yang dapat menjalankan fungsinya sebagai guru untuk negara-negara di dunia. Hal pertama yang dipelajari ASEAN dari EU adalah integrasi regionalnya. Kesuksesan EU dalam proses integrasi menjadikan ASEAN tertarik untuk bekerja sama dalam bentuk proses "belajar-mengajar". EU dianggap memiliki pengetahuan yang lebih banyak mengenai proses integrasi dalam suatu komunitas internasional. Keberhasilan EU dalam proses integrasi bagi negara-negara anggotanya ditunjukkan dalam European Monetery Union (EMU). EMU merupakan pengintegrasian yang berlangsung pada periode tahun 19691999 hingga saat iini yang diwujudkan dengan terciptanya pemberlakuan satu mata uang resmi dibawah EU yakni euro (EU, 2014). Pada awal pembentukannya, EMU beranggotakan empat negara partisipan yakni Spanyol, Portugal, Yunani dan Irlandia. EMU ini kemudian diikuti dengan sebuah langkah besar untuk EU (yang pada saat itu masih bernama European Economic Community) yakni dengan ditandatanganinya Perjanjian Maastricht yang menghasilkan pembentukan satu nama entitas politik yang disebut "European Unoion". Tahun 1986, mulai ditandatanganinya Single European Act (SEA) oleh anggorta-anggota EU yang menandai terbentuknya "pasar tunggal". Single European Act (SEA) instrumen-instrumen yang dapat mendorong terbentuknya pasar tunggal di EU. Salah satu bentuknya adalah dengan emungkinkan terjadinya lintas sumber daya manusia, barang, jasa, dan modal yang dapat bergerak secara bebas ke sesama negara anggota. Hal ini dimaksudkan untuk membuka peluang terciptanya lapangan pekerjaan dan pertumbuhan Eropa yang lebih maju. Selain lapangan pekerjaan, SEA diharapkan juga dapat menciptakan iklim pasar modal yang lebih terintegrasi melalui penyaluran investasi dana lintas negara anggota. Salah satu contohnya adalah rezim mengenai mobilitas pekerja. Tujuan dari adanya rezim ini adalah menjamin mobilitas sumber daya manusia yang lebih be- 
bas dan penyesuaian keterampilan dengan lapangan pekerjaan yang ada. Dibawah rezim ini, EU juga menjamin hak sosial pekerja dan memastikan pasar tenaga kerja Eropa yang adil (European Commission, 2018).

Hal kedua yang dipelajari oleh ASEAN adalah proses terbentuknya komunitas-komunitas EU yang dinilai mendorong kemajuan kerja sama intraregional. Tujuan awal terbentuknya EU hanya memberlakukan rezim integritas ekonomi di tanah Eropa saja, akan tetapi, saat ini kerja sama tersebut telah berkembang dalam pengintegrasian di bidang-bidang yang lain seperti sosial, politik, pertahanan, hukum nasional, hingga kebijakan luar negeri masing-masing anggota.

Struktur organisasi EU memiliki tiga pilar kerja sama yaitu European Community, Common Foreign and Security Policy (CFSP), serta Justice and Home Affairs. Tidak jauh berbeda, dalam kesepakatan Bali Concord II pada tahun 2003 telah menghasilkan terbentuknya tiga pilar komunitas ASEAN, yakni ASEAN Security Community (ASC), ASEAN Economy Community (AEC), dan ASEAN Sosiocultural Community (ASCC). Ketiga pilar tersebut mencerminkan keinginan ASEAN untuk lebih maju sebagai satu 'masyarakat ASEAN'. Kemudian, program Enhanced Regional EU-ASEAN Dialog EU Instrument (E-READI) dan Enhanced ASEAN Regional Integration Support from the EU (ARISE Plus) muncul sebagai bentuk kerja sama ASEAN-EU.

E-READI merupakan program kerja sama yang memfasilitasi forum dialog antara EU dan ASEAN dalam area kebijakan di seluruh pilar komunitas ASEAN (Sekretariat Nasional ASEAN-Indonesia, 2017). Instrumen dialog E-READI mengacu pada pengalaman Eropa dalam intergrasi regional. Program kerja sama ini merupakan upaya ASEAN untuk mendapat banyak pelajaran dari EU dalam hal integrasi regional. Sedangkan Program ARISE Plus-Regional terdiri dari komponen pasar tunggal ASEAN yaitu standar, fasilitas perdagangan, dan bea cukai (Sekretariat Nasional ASEAN-Indonesia, 2017). Program ARISE Plus-Regional ini merupakan bentuk perwujudan upaya ASEAN untuk dapat mengadopsi manfaat dalam bekerja sama dengan EU, terutama dalam proses pengintegrasian ekonomi regionalnya. Program tersebut memiliki fokus khusus pada negara-negara CLMV (Kamboja, Laos, Myanmar, dan Vietnam) dan bekerja sama dengan pihak-pihak yang relevan seperti Sekretariat ASEAN, Badan Sektoral ASEAN, Kementerian di negara anggota ASEAN, serta sektor swasta (European External Action Service, 2018). Dalam upaya mewujudkan ASEAN Vision 2020, maka dibentuklah High Level Task Force (HLTF) untuk merumuskan modalitas menuju ASEAN Economic Union (Kementerian Perindustrian RI, 2003).

Forum dialog ASEAN-EU menjadikan ASEAN sangat terinsipiransi oleh integrasi regional EU. Seperti sebuah kritik dari David Martin Jones and Michael L. R. Smith dalam ASEAN's Imitation Community yang mengungkapkan bahwa ASEAN merupakan bentuk imitation community, yakni sebuah perwujudan dari euforia sesaat dan meniru cara-cara yang telah 
diterapkan sebelumnya oleh negara-negara maju (dalam kasus ini Eropa) (Martin, 2001). Hal ini dibuktikan ketika dalam proses pengintegrasiannya, ASEAN banyak belajar dari EU. MEA (Masyarakat Ekonomi ASEAN) sebagai pasar tunggal ASEAN juga merupakan bentuk pembelajaran ASEAN dari EU yakni dari Single European Act (SEA). MEA diharapkan mampu mendorong pertumbuhan ekonomi ASEAN yang belum optimal. Selain iut negara ASEAN juga mengharapkan pertumbuhan share intra-ASEAN trade dapat meningkat seiring dengan upaya peningkatan integrasi ekonomi ASEAN. Sebelumnya, tercatat pada tahun 2013 bahwa share intra- ASEAN trade hanya dapat bertahan pada angka $24-25 \%$ saja dan porsi perdagangan luar negeri negara ASEAN yang terbesar juga masih dengan negara diluar anggota ASEAN itu sendiri (CNN Indonesia, 2015). Pertemuan-pertemun ASEAN dan EU didominasi oleh kebutuhan akan konsultasi yang dilakukan ASEAN terhadap EU. Selain konsultasi, ASEAN juga membutuhkan pertukaran informasi mengenai politik, keamanan dan ekonomi, serta bidang-bidang lainnya dari masing-masing regional dari EU. Beberapa bentuk pertemuan ASEAN dengan anggota EU antara lain Komite ASEAN-Brussel, Komite ASEAN-London, dan Komite ASEAN-Paris.

\section{Pelajaran EU dari ASEAN: Kekuatan Normatif dan Seni Pragmatisme}

Institusi mengadopsi norma dan prinsip perilaku guna memfasilitasi kontak yang teratur, berbagi informasi, dan membangun kepercayaan anggotanya. Ide dan norma transnasional berdampak pada perubahan kelembagaan (Acharya, 2005:178), namun dampak adaptasi ide dan norma merupakan faktor penyebab mengapa dan bagaimana suatu norma diinternalisasi atau sebaliknya (Signel, 2015:3). Acharya (2004:244) berpendapat bahwa penyebaran norma-norma internasional dalam politik dunia tidak hanya mengenai apa dan bagaimana ide itu muncul, tapi juga terkait dengan ide mana dan ide siapa, karena ide dibangun agar sesuai dengan tradisi lokal yang baik untuk diterima.

Acharya (2004: 245-250) mengkaji bahwa localization sebagai upaya konstruksi aktif (melalui wacana, pembingkaian, grafting, dan pemilihan budaya) dari suatu ide dan norma internasional disebabkan oleh keinginan membentuk kesesuaian yang signifikan dengan kepercayaan dan praktik lokal. Hal ini menjelaskan mengapa aktor melakukan lokalisasi norma-norma tertentu. Aktor yakin bahwa norma-norma tersebut bisa digunakan untuk meningkatkan legitimasi dan kewenangan terkait dengan eksistensi mereka, tanpa mengubah identitas sosial yang sudah ada. Dinamika localization menjadi suatu sumber ide dan model pembangunan suatu institusi regional, tanpa harus direplikasi institusi lain.

Dalam konteks pembangunan ketahanan regional, upaya negara dalam menekan kerentanan dan ketidakamanan karena masalah keamanan 
sosial-budaya, ekonomi, dan geopolitik akan selalu menjadi faktor penting dalam lingkungan politik intra-states maupun inter-state. Peradaban Eropa yang relatif homogen dengan hal etnis dan agama akan bergeser pada multi-civilisational world. Meskipun pergeseran ini akan melahirkan tantangan yang tidak hanya dihadapi oleh Eropa saja, ada indikasi dimana pemerintah Eropa berada di bawah tekanan reaksi masyarakat yang cenderung mengalami xenofobia atas peningkatan migrasi displaced persons dari luar benua mereka sehingga membuka peran ASEAN untuk muncul mengadakan pelajaran bagi EU (Spandler, 2017).

ASEAN dan negara-negara anggotanya tampak menemukan titik jual yang unik di luar perdagangan, yaitu bagaimana pengalamannya menghadapi tantangan masyarakat yang sangat beragam. ASEAN telah mulai mengembangkan "kekuatan normatif baru" yang membawa organisasi ini lebih dekat ke tujuanpada level yang sama (Ifaireu, 2017). Meskipun istilah kekuatan normatif awalnya diciptakan untuk menggambarkan kemampuan EU dalam mempengaruhi ide-ide dan menciptakan lingkungan internasional yang menguntungkan dengan memproyeksikan nilainya di luar negeri, ASEAN memiliki kekuatan normatif yang dapat menjadi lesson learned bagi EU. Dengan aktif mengiklankan pengalaman mengenai heterogenitas sosial-budaya sebagai model untuk EU, pembuat kebijakan EU tertarik untuk memperdalam dialog tentang bagaimana cara negara-negara ASEAN mengelola masyarakat. Hal ini didukung bukti kedua pihak mengkonversikan ancaman terhadap ASEAN dan kepentingan bagi EU menjadi sebuah langkah baru dalam "growing and have a stake in closer cooperation, include: de-radicalisation or countering violent extremism, trafficking, [...] mediation (European Union, 2015).

Di sisi lain, ASEAN telah mengembangkan budaya atau seni pragmatisme untuk mengelola organisasinya. Pragmatisme ASEAN telah meningkatkan kinerja geopolitik dan berpendapat ahwa EU selalu berusaha konsisten secara ideologis serta tidak akan menerima anggota manapun kecuali mereka telah memenuhi serangkaian standar (Mahbubani, 2012). Dalam konteks ini, konsep pragmatisme EU berprinsip pada visi keamanan politik EU yang dapat dilihat melalui penekanan realistis menggunakan lensa yang lebih luas untuk menghubungkan dan memahami dunia, dan bukan bagaimana itu ingin melihat hubungannya. Sebagaimana dijelaskan oleh Tocci dalam 'A Stronger Europe in a Fragile World', gagasan pragmatisme utama membantu EU untuk membedakan apa yang diterima oleh nilai-nilai inti dan prinsip-prinsip mereka dengan menimbang konsekuensi praktis dari tindakan dan fokus pada praktik-praktik lokal dan dinamika (Azman, 2018: 38). Salah satu contohnya adalah bagaimana EU berprinsip pragmatis untuk mengembangkan daya tarik menurut nilai dan minatnya kepada negara-negara lain. 
Prinsip pragmatisme secara hipotesis menunjukkan bahwa ada solusi yang mendasari prinsip nurani moral dan pada saat yang sama memperhitungkan dimensi ekonomi, sosial dan politik dalam konflik secara realistis (Juncos, 2017: 6). Konsekuensi dari adanya konsep kunci yang tertanam dalam struktur ASEAN menciptakan rasa harapan di negara-negara, mengenai sejauh mana negara dapat mewujudkan keinginan regional yaitu untuk mencapai bentuk kesepakatan yang efektif. Kunci yang berkaitan dengan tingkat pragmatisme ASEAN adalah persepsi ancaman dengan fokus berdasarkan ketahanan regional dan identitas 'we-feeling' (Azman, 2018: 36). Dalam konteks ini, perlu dicatat bahwa dengan berprinsip pragmatis, bukan berarti negara anggota ASEAN sama sekali tidak tahu apa yang penting bagi stabilitas regional. Idenya adalah pragmatisme berprinsip mengedepankan kondisi di mana respon terhadap masalah tertentu didasarkan pada perilaku moral regional dan pemikiran realistis mengenai kepentingan multidimensional masing-masing negara.

Prinsip pragmatisme sebagai fitur utama dalam StrategiGlobal EU 2016 (EUGS), bertujuan untuk menjembatani kesenjangan realitas mengenai peran konvensional EU yang mendasari prinsip-prinsip demokrasi yang tampaknya menjadi kurang relevan dan tidak efektif di luar lingkungannya (Azman, 2018:34). Oleh karena itu, diperlukan fleksibilitas yang didasarkan pada keterlibatan teknis, kepentingan bersama dan kepemilikan bersama di beberapa bidang sektoral untuk kebijakan yang konstruktif.

Perundingan keanggotaan Turki di EU yang secara resmi dimulai sejak 1987 dan dinegosiasikan kembali sejak Oktober 2005 menjalani proses yang sulit. Presiden European Comission, Jean-Claude Juncker, mengatakan bahwa keprihatinan akan masalah hak asasi manusia (HAM) adalah alasannya (Kompas, 2017). Meski Presiden Erdogan menyatakan Turki "bisa berdiri di atas kaki sendiri", (BBC, 2017) kesalahan geopolitik mendasar EU adalah kegagalannya memahami bahwa EU telah menciptakan sebuah konsep pengucilan (Mahbubani, 2012).

Ketika melihat konsep pragmatisme berprinsip di ASEAN dan EU, muncul beberapa indikasi dalam hal bagaimana kedua organisasi memiliki pendekatan serupa berkaitan dengan kerangka kerja politik-keamanan mereka. EU dikenal dengan pendekatan konvensional tentang "naming-and-shaming", "sanksi" dan menuntut konvergensi pada ketentuan-ketentuannya untuk mengimplementasikan aturan-aturan Eropa atas pihak-pihak yang bertikai. Dengan demikian, terdapat konsekuensi jika pendekatan EU yang liberal diterapkan di regional lain. Pragmatisme EU berkontribusi pada penguatan rezim yang berkaitan dengan kasus Suriah, Turki dan Rusia serta telah memperburuk kedamaian di lingkungan terdekatnya, seperti yang terlihat di Mesir, Suriah, Libya, Mali, Somalia, Sudan Selatan dan Yaman (Azman, 2018:38). Kontras dengan ASEAN yang 
memiliki standar yang "inklusif" dan memberi pengecualian, keputusan ASEAN untuk menerima Myanmar pada 1997 merupakan keputusan geopolitik sangat brilian. ${ }^{1}$ ASEAN tidak menjatuhkan sanksi pada Myanmar saat menghadapi tantangan sulit dalam proses demokratisasi dan isu pelanggaran HAM. Alih-alih, ASEAN melibatkan Myanmar lebih dalam. Myanmar yang dikenal sebagai negara ASEAN yang paling "interfered" juga telah memberikan contoh yang berguna dan praktis untuk bekerja demi kebaikan regional bersama. Secara khusus, Ali Alatas, mantan Menteri Luar Negeri Indonesia, telah memperkenalkan pendekatan 'enhanced interactions', yang dapat mencakup peer pressure atau friendly advice yang dianggap sah jika situasi domestik dapat berkonsekeunsi untuk wilayah yang lebih luas (EU Centre in Singapore, 2010). Pendekatan ini didukung oleh para anggota ASEAN pada tahun 1998. Kesediaan Myanmar untuk bekerja dengan ASEAN dalam menangani implikasi krisis kemanusiaan dan membahas situasi yang lebih baru di Rakhine, menggambarkan bahwa Myanmar memang mengakui di mana kepentingan nasional dan prinsip-prinsip regional dapat dikompromikan. Sehingga dapat dilihat bahwa proyek integrasi regional dari pengalaman masa lalu untuk kesuksesan di masa depan (Myanmartimes, 2017). Hal ini tentu menyediakan satu platform geopolitik di mana kekuatan negara berkembang di Asia Tenggara dapat bertemu.

\section{Kesimpulan}

Praktik kerja sama antara ASEAN dan EU kinisudah mencapai tahap mutualisme di keduanya, yaitu dengan sama tercapainya tujuan dari kedua organisasi tersebut. Dengan perbedaan karakteristik, struktur dan GDP antara ASEAN dan EU tentu menunjukkan secara jelas ketimpangan yang terjadi diantara keduanya organisasi.Namun, ketimpangan tersebut justru mendorong adanya kerja sama yang mutual antara ASEAN dan EU. Mulai dari pihak ASEAN yang mendapatkan keuntungan dalam perluasan lapangan kerja dan mendapatkan investasi dari EU, dan dari EU sendiri lebih mudah mengekspor di wilayah ASEAN. ASEAN sendiri merupakan bentuk imitation community, yakni sebuah perwujudan dari euforia sesaat dan meniru cara-cara yang telah diterapkan sebelumnya oleh negara-negara maju, yang dalam kasus ini adalah Eropa. Kesepakatan Bali Concord II pada tahun 2003 telah menghasilkan terbentuknya tiga pilar komunitas ASEAN, yakni ASEAN Security Community (ASC), ASEAN Economy Com-

1 Ali Alatas mengatakan bahwa jika Myanmar dikeluarkan dari ASEAN, itu akan terjadi menjadi rebutan antara China dan India untuk pengaruh geopolitik. ASEAN perlu meminimalkan persaingan SinoIndian. (Mahbubani, 2012) 
munity (AEC), dan ASEAN Sosiocultural Community (ASCC). Ketiga pilar tersebut mencerminkan keinginan ASEAN untuk lebih maju sebagai satu 'Masyarakat ASEAN'. Dari contoh diatas pun menjelaskan bahwa ASEAN juga ingin melakukan intergritas yang solid sama halnya dengan EU.

Oleh karena itu, dapat disimpulkan bahwa hubungan kerja sama ASEAN-EU merupakan hubungan kerja sama yang baik. Dibuktikan dengan pengadopsian EU terhadap nilai-nilai ASEAN terutama dalam bidang sosial, politik, dan pertahanan. Heterogenitas yang dimiliki ASEAN menarik EU untuk belajar mengenai bagaimana cara mengelola masyarakat, hal ini dibuktikan dengan langkah kedua belah pihak dalam "growing and have stake in closer coorperation, include: de-radcalisation/countering, violent extremism, trafficking, mediation. Nilai pragmatisme ASEAN menjadi salah satu hal yang perlu dipelajari oleh EU, terutama dalam rangka memenuhi Strategi Global EU 2016 yang salah satu fitur utamanya adalah prinsip pragmatism, dan cita-cita untuk menjembatani kesanjangan realitas realitas.

\section{Daftar Pustaka}

Armeia, R. (2015) Mendag: Pasar Tunggal ASEAN, Gravitasi Ekonomi Masa Depan [Online], CNN Indonesia, 27 April. Tersedia di: <https:// www.cnnindonesia.com/ekonomi/20150427131011-92-49477/ mendag- pasar-tunggal-asean-gravitasi-ekonomi-masa-depan> [diakses 22 November 2018].

Azman \& Kumar. (2018) Asean's Principled Pragmatism and the Evolving Normative Security Strategy on the South China Sea [Online], Libraries Provider, 3 Januari. Tersedia di:<https://aei.um.edu. my/docs/librariesprovider12/default-document library/aseanprincipled-pragmatism-azman-and-kumar-pp-33--- 48.pdf?sfvrsn=2> [diakses 22 November 2018].

Barkin, J. S. (2003). Realist Constructivism. International Studies Review, 5(3) pp. $325-42$

BBC. (2017) Erdogan: Tak masalah jika EU tidak menerima keanggotaan Turki [Online], 4 Juni. Tersedia di: $<$ https://www.bbc.com/indonesia/dunia-40581774> [diakses 25 September 2018].

Christainsen, T. (2001). European Integration and Regional Cooperation. New York: Oxford University Press.

Community Posts. (2012) Can the EU learn lessons from ASEAN? [Online], 23 Maret. Tersedia di: <http://mahbubani.net/articles\%20by\%20dean/ can-the-eu-learn-lessons-from-asean.pdf $>$ [diakses 25 September 2018].

Martin, J. D. (2002). ASEAN's Imitation Community [Online], Foreign Policy Institute, 27 Mei. Tersedia di:<https://www.fpri.org/article/2002/01/ 
aseans-imitation-community/> [diakses 30 Oktober 2018] European External Action Service. (2018) ASEAN dan EU meluncurkan program unggulan terkait dialog kebijakan dan integrasi ekonomi [Online], 2 Juni.Terseia di: <https://eeas.europa.eu/delegations/indonesia/43058/asean-dan-uni-eropa-meluncurkan-program-unggulan-terkait-dialog-kebijakan-dan-integrasi_id> [diakses 25 September 2018].

EU Centre in Sngapore. (2010) EU-ASEAN Relations: The Importance of Values, Norms and Culture [Online], 8 Juni. Tersedia di: $<\mathrm{http}: / /$ aei.pitt.edu/14480/1/EUASEAN-AlecuFlers-8June2010.pdf> [diakses $22 \quad$ November 2018].

European Union. (2014) Eropean Monetary Union Story [Online], 13 Maret. Tersedia di: <http://ec.europa.eu/archives/emu_history/part_a. $\mathrm{htm}>$ [diakses 23 September 2018].

European Union. (2015) Joint Communication to the European Parliament And The Council[Online], 24Januari. Tersedia di:<https://eurlex. europa.eu/legalcontent/EN/TXT/PDF/?uri=JOIN:2015:22:FIN\&f rom=EN $>$ [diakses 25 September 2018].

European Commision. (2018) Internal Market : A deeper and fairer internal market [Online], 4 Juni. Tersedia di: <https://ec.europa.eu/ commission/priorities/internal-market_en?> [diakses 26 November 2018].

IFAIR. (2017) What ASEAN can Teach the EU [Online], 9 Desember. Tersedia di: <http://ifair.eu/asean-can-teach-eu/> [diakses 25 September 2018].

Jackson, P. T. \& Nexon D.H. (2009). Paradigmatic Faults in International Relations Theory. International Studies Quarterly, 53(4), pp. 907-30

Jackson, R. (2009). Pengantar Studi Hubungan Internasional. Yogyakarta: Pustaka Pelajar.

Kementerian Perindustrian RI. (2003) Hasil Pertemuan Menteri-Menteri Bidang Perdagangan ASEAN Di Luang Prabang, Laos [Online], 7 September. Tersedia di: <http://www.kemenperin.go.id/ artikel/582/Hasil-Pertemuan-Menteri-Menteri-Bidang-Perdagangan-ASEAN-Di-Luang-Prabang,-Laos> [diakses 23 September 2018].

Kementrian Luar Negeri Indonesia. (2008) Kerja sama ASEAN dan Mitra Wicara [Online], 22 Juli. Tersedia di: <https://www. kemlu.go.id/Other\%20Documents/ASEAN/Kerjasama\%20ASE AN\%20dan\%20Mitra\%20Wicara.PDF> [diakses 24 September 2018].

Kompas. (2017) EU Tolak Permohonan Keanggotaan Turki karena Masalah HAM [Online], 14September.Tersediadi:<https://internasion- 
al.kompas.com/read/2017/09/14/07283791/uni-eropa-tolak-permohonan-keanggotaan-turki-karena-masalah-ham> [diakses 25 September 2018].

Mallow, S. (2016) Higher Education in ASEAN [Online], 6 Oktober. Tersedia di: <https://iau-aiu.net/IMG/pdf/iau_higher_education_in_asean-2.pdf $>$ [diakses 30 September 2018]

Myanmar Times. (2017). ASEAN and Myanmar - past, present and future [Online], 26 Juli. Tersedia di: <https://www.mmtimes.com/asean-focus/27162-asean- and-myanmar-past-present and-future. html> [diakses 25 September 2018].

Petrikor, S. W. (2016). Sejarah EU: Mendedah Masa Lalu dan Isu Terkini. Solo: Azka Pressindo.

Rangganawati, O. (2005). Asean dalam Perspektif Pluralisme dan $\quad \mathrm{N}$ e ofungsionalisme. Majalah Ilmiah Unikom, 17 Mei, p.18.

Reus-Smit, Haas C. (2001). Human Rights and the Social Construction of Sovereignty. Review of International Studies, 27, pp. 519-38.

Sekretariat Nasional ASEAN-Indonesia. (2017) Kerja sama Eksternal [Online], 22 Juni. Tersedia di: <http://setnas-asean.id/kerja-sama-eksternal> [diakses 23 September 2018].

Sil, R., \& Katzenstein, P. J. (2010). Beyond Paradigm. Political Analysis, pp. 24-48.

The Diplomat. (2017) What Can ASEAN Teach the EU? [Online], 1 Juli. Tersedia di: <https://thediplomat.com/2017/01/what-can-asean-teachthe-eu/> [diakses 23 September 2018].

Thuzar, M. (2012) ASEAN and the European Union Lessons in Integration [Online], e.ir.Info, 7 Oktober. Tersedia di: <http://www.e-ir.info/2012/10/07/asean-and- the-european-union-lessons-in-integration/> [diakses 25 September 2018].

Winarno, B. (2014). Dinamika Isu Isu Global Kontemporer. Jakarta: CAPS. 